\title{
PENGARUH MODERASI SELF EFFICACY PADA HUBUNGAN PENGETAHUAN KEWIRAUSAHAAN TERHADAP MINAT BERWIRAUSAHA DI UNIVERSITAS PENDIDIKAN GANESHA
}

\author{
N.M. Srianggareni ${ }^{1}$, K.K.Heryanda ${ }^{2}$, N.L.W.S. Telagawathi ${ }^{3}$ \\ 1,2,3 Jurusan Manajemen, Universitas Pendidikan Ganesha, Singaraja \\ e-mail: madesrianggareniz@gmail.com, krisna.heryanda@gmail.com, gemilangsuryawan@gmail.com
}

\begin{abstract}
Abstrak
Penelitian ini bertujuan untuk menguji tentang (1) Pengaruh pengetahuan kewirausahaan terhadap minat berwirausaha kelompok mahasiswa wirausaha di Undiksha, (2) Pengaruh self-efficacy terhadap minat berwirausaha pada kelompok mahasiswa wirausaha di Undiksha, dan (3) Pengaruh self-efficacy sebagai variabel moderasi pada hubungan pengetahuan kewirausahaan terhadap minat berwirausaha. Desain penelitian ini adalah penelitian kuantitatif kausal. Subjek dalam penelitian ini adalah mahasiswa yang lulus dalam seleksi Program Mahasiswa Wirausaha pada tahun 2019 yang berjumlah 39 tim, sedangkan objek yang digunakan adalah pengetahuan kewirausahaan, self-efficacy, dan minat berwirausaha. Data dikumpulkan dengan cara menyebarkan kuesioner kepada responden penelitian dan kemudian dianalisis dengan teknik analisis regresi dengan variabel moderasi. Hasil penelitian (1) Pengetahuan kewirausahaan berpengaruh positif dan signifikan terhadap minat berwirausaha, (2) self-efficacy berpengaruh positif dan signifikan terhadap minat berwirausaha, dan (3) self-efficacy sebagai variabel moderasi berpengaruh negatif dan signifikan pada hubungan pengetahuan kewirausahaan terhadap minat berwirausaha.
\end{abstract}

Kata Kunci: minat berwirausaha, pengetahuan kewirausahaan, self-efficacy

\begin{abstract}
This research aims to examine (1) The effect of entrepreneurial knowledge on entrepreneurial interest in entrepreneurship student groups in Undiksha, (2) The effect of self-efficacy on entrepreneurial interest in entrepreneurship student groups in Undiksha, and (3) The effect of self-efficacy as a moderating variable on knowledge relations entrepreneurship towards entrepreneurship interests. The design of this research is causal quantitative research. The subjects in this study were students who passed the student entrepreneurship program selection in 2019 totaling 39 teams, while the objects used were entrepreneurial knowledge, self-efficacy, and entrepreneurial interest. Data were collected by distributing questionnaires to research respondents and then analyzed by regression analysis techniques with moderating variables. The results of the study (1) entrepreneurial knowledge has a positive and significant effect on entrepreneurial interest, (2) self-efficacy has a positive and significant effect on entrepreneurial interest, and (3) self-efficacy as a moderating variable has a negative and significant effect on the relationship of entrepreneurial knowledge to entrepreneurial interest.
\end{abstract}

Keywords : entrepreneurial interest, entrepreneurial knowledge, self-efficacy 


\section{PENDAHULUAN}

Permasalahan ketenagakerjaan akibat ketidakseimbangan pencari kerja dan ketersediaan pekerjaan yang mengakibatkan terjadi peningkatan persentase pengangguran. Cara mengatasinya dengan memperkenalkan dunia wirausaha dirasa mampu mengurangi jumlah pengangguran karena dapat membuka lapangan pekerjaan. Penduduk negara maju memiliki jumlah wirausaha rata-rata diatas 14\%. Sementara Indonesia masih $3,1 \%$ dari jumlah penduduk yakni berjumlah 266 juta jiwa, masih berada di bawah Singapura yang telah mencapai 7\% dan Malaysia mencapai 5\% (Kompas.com), sehingga untuk dapat mencapai persentase yang disyaratkan tersebut maka diperlukan adanya pertumbuhan wirausaha. Manfaat dari berwirausaha yaitu, dapat menambah daya tampung tenaga kerja, meningkatkan pendapatan masyarakat, dan dapat berkontribusi untuk meningkatkan perekonomian bangsa melalui pembayaran pajak sebagai bentuk pertanggungjawaban kepemilikan usaha.

Generasi muda yang terdidik menjadi sumber daya potensial yang dapat mengikuti perubahan di lingkungan masyarakat. Generasi muda yang memiliki kapasitas intelektual, diharapkan mampu mengembangkan potensi untuk membangun kemajuan bangsa. Pembangunan tersebut akan berhasil bila didukung

dengan kegiatan wirausaha yang dapat menambah lapangan pekerjaan. Namun kenyataannya para lulusan pendidikan formal cenderung memilih untuk mencari pekerjaan, yang membuat persaingan kerja menjadi semakin ketat. Keadaan ini mengharuskan para pekerja dapat menciptakan wirausaha yang inovatif, untuk mengurangi jumlah pengangguran.

Salah satu cara untuk menyiapkan generasi muda yang mampu menciptakan inovatif dalam berwirausaha adalah dengan memberikan pengetahuan kewirausahaan. Seseorang dianggap memiliki pengetahuan kewirausahaan yaitu mampu menguasai pengetahuan dasar kewirausahaan, mampu melihat peluang dan mampu memahami aspek-aspek usaha. Pengetahuan kewirausahaan dapat diajarkan melalui kegiatan belajar mengajar dan kegiatan pelatihan seperti seminar kewirausahaan. Kewirausahaan merupakan bidang ilmu yang dapat disebarluaskan dan telah mengalami perkembangan di lembaga kependidikan, sehingga generasi muda berpeluang mendapatkan pengetahuan kewirausahaan (Alma, 2008). Memiliki pengetahuan dasar kewirausahaan berguna sebagai pondasi untuk menciptakan inovasi dan peluang usaha yang menguntungkan.

Mendapatkan pengetahuan kewirausahaan dapat memicu minat seseorang untuk berwirausaha. Minat berwirausaha menjadi suatu hal yang berpusat pada ketertarikan, perasaan senang dan adanya dorongan untuk berwirausaha (Ulfatun, dkk. 2015:56). Minat terhadap kewirausahaan perlu dikembangkan pada diri seorang wirausahauntuk dapat menjalankan usaha berdasarkan komitmen. Memiliki minat berwirausaha dapat membuat seseorang memiliki ketekunan dalam mencari dan memanfaatkan peluang untuk mewujudkan wirausaha (Uswaturrasul dan Sisilia, 2015). Seseorang yang minat terhadap wirausaha akan memiliki dorongan untuk memenuhi tujuan yang ingin di capai.

Minat seseorang untuk menjadi wirausahawan, akan terwujud jika rasa kepercayaan diri seseorang lebih besar dari pada situasi yang sedang dihadapai (Suparyanto, 2016). Efikasi diri atau keyakinan diri yang dimiliki mahasiswa akan memberikan keberhasilan dan menciptakan kepuasan dalam berwirausaha. Efikasi diri turut berkontribusi dalam perkembangan pendidikan kewirausahaan dan rancangan kegiatan berwirausaha (Bagheri, et all, 2013). Adanya keyakinan yang dimiliki oleh wirausahawan dalam mengelola usaha akan menciptakan kemauan dan kesiapan yang matang dalam mewujudkan keberhasilan usaha. Wirausahawan yang yakin dengan kemampuan diri mampu mengelola suatu pekerjaan dengan cara sistematis, terencana, efektif dan efisien (Suryana, 2016).

Perguruan tinggi berperan dalam mengubah pandangan mahasiswa mengenai dunia kerja. Salah satu perguruan tinggi yang turut mengembangkan budaya kewirausahaan adalah Universitas Pendidikan Ganesha. Program mahasiswa wirausaha di Universitas Pendidikan Ganesha berada dibawah naungan Unit Pelaksana Teknis Pengembangan Karir dan Kewirausahaan Mahasiswa (UPT PKKM), bertujuan untuk memberikan pengetahuan dan keterampilan sebagai upaya menumbuhkan kemandirian para lulusan. Universitas Pendidikan 
Ganesha terus berupaya untuk meningkatkan minat mahasiswa, untuk dapat menciptakan usaha mandiri dengan cara memberikan pengetahuan kewirausahaan melalui kelas pelatihan kewirausahaan yang di kemas dalam bentuk seminar umum dan program pengembangan kewirausahaan.

Program mahasiswa wirausaha di UNDIKSHA dilaksanakan setiap tahunnya. Jumlah tim yang terlibat dalam mengumpulkan proposalselalu bervariasi setiap tahunnya, seperti pada tahun 2015 terdiri dari 38 tim, tahun 2016 terdiri dari 26 tim, pada tahun 2017 terdiri 23 tim, di tahun 2018 terdiri dari 40 tim, dan di tahun 2019 sebanyak 39 tim (Data UPT PKKM, 2019). Kelompok yang lulus seleksi diharuskan untuk menjalankan program dan menjaga kehidupan usaha yang telah dibiayai sesuai dengan anggaran yang diusulkan. Namun yang terjadi berdasarkan hasil pengamatan, aplikasi program wirausaha yang dibuat hanya dijalankan selama masa monitoring berlangsung. Kenyataannya tidak semua kelompok mahasiswa wirausaha memiliki minat untuk melanjutkan pengalaman berwirausaha setelah menyelesaikan pendidikan.

Kelompok mahasiswa yang telah mendapatkan pengetahuan kewirausahaan belum memiliki minat berwirausaha karena kurangnya kepercayaan diri untuk mengelola usaha, kurangnya kesiapan untuk mengatasi resiko usaha, dan membuka usaha memerlukan modal awal yang masih menjadi pertimbangan. Dalam penelitian Artiandewi (2016) menyatakan keyakinan diri seseorang yang mampu menumbuhkan minat berwirausaha, jika tidak ada keyakinan diri maka kecil kemungkinan memiliki minat berwirausaha. Dalam penelitian Ekpe \& Mat (2012) menunjukkan bahwa efikasi diri sangat berpengaruh pada minat kewirausahaan dan di imbangi dengan pendidikan. Rendahnya tingkat pengetahuan kewirausahaan yang dimiliki mahasiswa menyebabkan mereka ragu untuk memulai usaha, karena belum memahami dengan baik mengenai aspek-aspek wirausaha. Sedangkan menurut Mustofa (2014) menyatakan pengetahuan kewirausahaan memiliki pengaruh terhadap minat berwirausaha.

Berdasarkan latar belakang penelitian yan telah dipaparkan, maka rumusan masalah dalam penelitian ini adalah: (1) Bagaimana pengaruh pengetahuan kewirausahaan terhadap minat berwirausaha kelompok mahasiswa wirausaha? (2) Bagaimana pengaruh efikasi diri terhadap minat berwirausaha kelompok mahasiswa wirausaha? (3) Bagaimana pengaruh efikasi diri dalam hubungan pengetahuan kewirausahaan terhadap minat berwirausha kelompok mahasiswa wirausaha?

Tujuan dari penelitian ini adalah untuk mengetahui hal-hal sebagai berikut : (1) Menguji pengaruh pengetahuan kewirausahaan terhadap minat berwirausaha kelompok mahasiswa wirausaha. (2) Menguji pengaruh efikasi diri terhadap minat berwirausaha kelompok mahasiswa wirausaha. (3) Menguji pengaruh efikasi diri dalam hubungan pengetahuan kewirausahaan terhadap minat berwirausha kelompok mahasiswa wirausaha.

\section{KAJIAN PUSTAKA DAN PERUMUSAN HIPOTESIS \\ Hubungan Pengetahuan Kewirausahaan terhadap Minat Berwirausaha}

Menjadi wirausahawan yang berhasil disebabkan karena seseorang memiliki kemauan, kemampuan, dan pengetahuan (Suryana, 2016). Jika hanya memiliki kemauan tanpa kemampuan, maka usaha yang dirintis akan sulit berkembang. Serta jika hanya memiliki pengetahuan dan kemampuan yang tidak disertai dengan kemauan maka wirausaha tidak dapat terwujud. Sebuah kemauan merupakan minat yang kuat seseorang untuk dapat melakukan apa yang diinginkan. Pengetahuan kewirausahaan yang dimiliki seseorang dapat memicu adanya minat berwirausaha. Pendidikan formal dan pengalaman bisnis-bisnis kecil yang dimiliki oleh seseorang dapat menjadi potensi utama untuk menjadi wirausaha yang berhasil (Alma, 2008). Akan ada daya tarik seseorang terhadap wirausaha setelah memperoleh informasi dari kegiatan pelatihan, seminar dan praktik kewirausahaan.

Mahasiswa yang memiliki pengalaman wirausaha setelah mendapatkan pengetahuan kewirausahaan akan memicu terciptanya peluang untuk berwirausaha. Sehingga dapat diukur jika memiliki pengetahuan kewirausahaan yang baik maka akan ada pola pikir yang kreatif dan inovatif. Hal ini sejalan dengan hasil penelitian Mustofa (2014) yang menunjukkan bahwa 
pengetahuan kewirausahaan berpengaruh positif dan signifikan terhadap minat berwirausaha. Di dukung pula dari penelitian Anggraeni dan Nurcaya (2016) dan Aprilianty (2012) menunjukkan pengetahuan atau pendidikan kewirausahaan dapat memberikan pengaruh yang postif terhadap minat berwirausaha.

$\mathrm{H}_{1}$ : Terdapat pengaruh pengetahuan kewirausahaan terhadap minat berwirausaha.

\section{Hubungan Efikasi Diri terhadap Minat Berwirausaha}

Dalam mencapai tujuan yang diinginkan hal yang terpenting dimiliki seseorang adalah keyakinan diri atau self efficacy yang saling mempengaruhi niat dan tindakan seseorang. Keberhasilan dan pelaksanaan pekerjaan dapat ditentukan dengan adanya self efficacy. Munculnya kepercayaan diri pada seseorang berasal dari pengalaman-pengalaman yang pernah di alami. Menurut Anggraeni dan Nurcaya (2016) efikasi diri merupakan kepercayaan individu terhadap kemampuan dirinya dalam memulai suatu usaha, mengelola usaha, dan yakin akan berhasil dalam berwirausaha. Keyakinan seseorang memberikan dampak positif terhadap pengambilan keputusan, dan mampu mengahadapi tantangan dengan strategi yang penuh pertimbangan.

Karakter peracaya dengan kemampuan diri serta memiliki kematangan mental untuk memulai usaha diperlukan pada seorang wirausahawan untuk dapat mencapai kesuksesan berwirausaha. Hal ini dibuktikan dari hasil penelitian Ekpe \& Mat (2012) bahwa efikasi diri merupakan faktor yang paling berpengaruh terhadap minat berwirausaha. Hasil tersebut sejalan dengan penelitian Mustofa (2014) yang menyatakan jika memiliki efikasi diri yang tinggi, maka akan semakin tinggi pula minat berwirausaha dan sebaliknya jika efikasi diri rendah maka akan mengurangi minat berwirausaha. Dalam hasil penelitian oleh Puspitaningsih (2014), Owoseni (2014) dan Wiyanto (2014) menyatakan pula bahwa efikasi diri berpengaruh positif signifikan terhadap minat berwirausaha.

$\mathrm{H}_{2}$ : Terdapat pengaruh efikasi diri terhadap minat berwirausaha

\section{Efikasi Diri Memoderasi Hubungan Pengetahuan Kewirausahaan terhadap Minat Berwirausaha}

Menumbuhkan minat berwirausaha bisa dilakukan dengan cara memberikan pengetahuan dasar kewirausahaan. Minat berwirausaha adalah adanya keinginan dan ketertarikan seseorang untuk berwirausaha tanpa ada rasa takut dengan resiko usaha (Anggraeni dan Harnanik, 2015). Seseorang yang berminat untuk berwirausaha tidak mampu mengaplikasikan tindakannya jika tidak memiliki pengetahuan kewirausahaan. Pengetahuan kewirausahaan diberikan untuk memberi tahu cara mencari peluang usaha, memahami aspekaspek usaha dan memberikan gambaran tentang dunia usaha yang sesungguhnya. Mustofa (2014) berpendapat bahwa, pengetahuan kewirausahaan adalah keahlian seseorang dalam menghasilkan inovasi dan peluang dari berfikir kreatif untuk memperoleh keuntungan. Memiliki pengetahuan kewirausahaan, keterampilan menciptakan peluang dan motivasi pada umumnya dapat membuat seorang wirausaha mampu mencapai kesuksesan (Suryana, 2016:81).

Dalam mewujudkan keinginan berwirausaha, seseorang perlu memiliki kepercayaan diri, keyakinan dan optimisme untuk dapat memulai sebuah usaha. Didukung oleh pendapat Daryanto (2012:8) yang menyatakan bahwa seorang wirausaha dengan efikasi diri akan lebih optimis dan memiliki keyakinan yang kuat dari kemampuan yang di miliki untuk mewujudkan keberhasilan usaha. Wirausahawan yang memiliki efikasi diri akan terlihat percaya diri untuk mengelola usaha, mampu memimpin tim kerja, memiliki kemauan yang kuat untuk memulai sebuah usaha dan memiliki keyakinan terhadap keberhasilan usaha (Andika dan Madjid, 2012). Berdasarkan penelitian yang dilakukan oleh Ekpe dan Mat (2012) menunjukkan bahwa seseorang dengan efikasi diri yang tinggi dapat mewujudkan keberhasilan dalam berwirausaha.

Adanya minat terhadap wirausaha, tercipta karena mendapatkan pengelaman dan informasi mengenai wirausaha. Pengetahuan kewirausahaan menurut Roxas, et all (2008) adalah informasi awal yang diterima sebagai modal untuk dapat mencapai kesuksesan berwirausaha. Seorang dengan wawasan luas mengenai wirausaha dan memiliki pengalaman akan mampu meningkatkan efikasi diri atau kepercayaan diri. Dalam penelitian Anggraeni dan Nurcaya (2016) menunjukkan pengetahuan kewirausahaan dapat memberikan pengaruh yang 
postif terhadap minat berwirausaha. Hal ini sejalan dengan pendapat Suryana (2016) menyatakan minat berwirausaha seseorang, yang memiliki pengetahuan kewirausahaan akan dipengaruhi oleh tingkat kepercayaan diri sebagai landasan yang kuat untuk menciptakan sebuah usaha.

$\mathrm{H}_{3}$ : Efikasi diri dapat memoderasi hubungan pengetahuan kewirausahaan terhadap minat berwirausaha

\section{METODE}

Penelitian ini menggunakan pendekatan kuantitatif kausal untuk memperoleh hasil yang menyatakan adanya pengaruh variabel bebas dan varabel terikat. Penelitian kuantitatif merupakan penelitian yang analisisnya lebih fokus pada data-data angka yang diolah dengan metode statistika. Penelitian ini dilakukan untuk mengetahui hubungan sebab akibat atau pengaruh dari variabel yang digunakan yaitu, pengetahuan kewirausahaan sebagai variabel independen, minat berwirausaha sebagai variabel dependen dan efikasi diri sebagai variabel moderasi.

Subjek dalam penelitian ini adalah kelompok mahasiswa yang lulus dalam seleksi program mahasiswa wirausaha (PMW) di Universitas Pendidikan Ganesha tahun 2019. Sedangkan yang menjadi objek dalam penelitian ini adalah pengetahuan kewirausahaan, minat berwirausaha dan efikasi diri.

Populasi adalah wilayah generalisasi yang terdiri atas objek atau subjek yang mempunyai kualitas dan karakteristik tertentu yang ditetapkan oleh peneliti untuk dipelajari dan ditarik kesimpulan (Sugiyono, 2016:61). Populasi yang digunakan dalam penelitian ini adalah ketua kelompok program mahasiswa wirausaha (PMW) tahun 2019 di Universitas Pendidikan Ganesha. Populasi dalam penelitian ini berjumlah 39 orang, yang menjadi subjek penelitian sebagai perwakilan setiap tim.

Teknik pengumpulan data yang digunakan dalam penelitian ini adalah kuesioner dan wawancara. Kuesioner merupakan cara pengumpulan data dengan menyiapkan daftar pernyataan-pernyataan yang terstruktur yang akan diberikan kepada responden untuk dijawab sesuai dengan variabel yang diteliti (Sugiyono, 2010). Kuesioner yang dibagikan disertai surat permohonan pengisian kuesioner dan penjelasan yang terkait dengan penelitian. Skala pengukuran yang digunakan yaitu skala likert dengan lima alternatif jawaban (1) $S S=5$, (2) $S=$ 4, (3) $\mathrm{KS}=3$, (4) TS $=2$, dan (5) STS $=1$. Teknik wawancara sebagai alat rechecking atau meniliti kebenaran informasi data yang belum di dapat atau sudah diperoleh sebelumnya. Teknik kuesioner dan wawancara ini dilakukan dengan kelompok program mahasiswa wirausaha di Universitas Pendidikan Ganesha pada tahun 2019.

Teknik analisis data yang digunakan dalam penelitian ini adalah analisis regresi variabel moderasi. Teknik ini digunakan untuk mengetahui pengaruh variabel bebas terhadap variabel terikat dan mengetahui pengaruh variabel moderasi terhadap hubungan variabel bebas dan variabel terikat. Terdapat tiga cara menguji regresi dengan variabel moderasi yaitu 1) Uji Interaksi, 2) Uji Selisih Nilai Mutlak, dan 3) Uji Residual. Penelitian ini menggunakan Uji Interaksi atau Moderate Regression Analysis (MRA) menurut Ghozali (2011) yaitu aplikasi regresi linear berganda dimana dalam persamaannya mengandung unsur interaksi (perkalian dua atau lebih variabel bebas). Pengujian data dalam penelitian ini menggunakan aplikasi Statistical Package for the Social Sciences (SPSS) versi 25.0 for windows yang merupakan sebuah program aplikasi yang digunakan untuk pembuatan analisis statistika. Sebelum data diolah dalam analisis regresi variabel moderasi, terlebih dahulu dilakukan pengujian asumsi klasik yang meliputi (1) Uji Normalitas, (2) Uji Multikolinearitas, (3) Uji Heterokedastisitas.

\section{HASIL DAN PEMBAHASAN HASIL Hasil}

Hasil analisis uji regresi dengan variabel moderasi dapat dilihat pada output SPSS pada Tabel 4.1 


\begin{tabular}{|c|c|c|c|c|c|}
\hline \multirow[b]{2}{*}{ Model } & \multicolumn{2}{|c|}{$\begin{array}{l}\text { Unstandardized } \\
\text { Coefficients }\end{array}$} & \multirow{2}{*}{$\begin{array}{c}\text { Standardized } \\
\text { Coefficients } \\
\text { Beta } \\
\end{array}$} & \multirow[b]{2}{*}{$\mathrm{T}$} & \multirow[b]{2}{*}{ Sig. } \\
\hline & B & Std. Error & & & \\
\hline $1 \quad$ (Constant) & -49.869 & 23.189 & & -2.151 & .038 \\
\hline $\begin{array}{l}\text { Pengetahuan } \\
\text { Kewirausahaan }\end{array}$ & 2.703 & .896 & 2.420 & 3.018 & .005 \\
\hline $\begin{array}{l}\text { Self Efficacy } \\
\text { Pengetahuan }\end{array}$ & 1.740 & .650 & 2.451 & 2.680 & .011 \\
\hline $\begin{array}{l}\text { Kewirausahaan* } \\
\text { Self Efficacy }\end{array}$ & -.055 & .025 & -3.113 & -2.201 & .034 \\
\hline
\end{tabular}

Sumber : Hasil Output SPSS 25.0 For Windows Analisis Regresi dengan variabel moderasi

Hipotesis penelitian pertama "Ada pengaruh Pengetahuan Kewirausahaan terhadap Minat Berwirausaha". Berdasarkan Tabel 4.1, Pengetahuan Kewirausahaan memiliki koefisien korelasi sebesar 2,703 dengan nilai signifikansi 0,005 $<0,05$ dan nilai t hitung sebesar 3,018 lebih besar dari $t$ tabel 1,688. Sehingga $\mathrm{H}_{0}$ ditolak yang berarti ada pengaruh positif signifikan Pengetahuan Kewirausahaan terhadap Minat Berwirausaha kelompok mahasiswa wirausaha di Universitas Pendidikan Ganesha.

Hipotesis penelitian kedua "Ada pengaruh Self Efficacy terhadap Minat Berwirausaha". Berdasarkan Tabel 4.1, Self Efficacy memiliki koefisien korelasi sebesar 1,740 dengan nilai signifikansi 0,011 < 0,05 dan nilai t hitung sebesar 2,680 lebih besar dari t tabel 1,688. Sehingga $\mathrm{H}_{0}$ ditolak yang berarti ada pengaruh positif signifikan Self Efficacy terhadap Minat Berwirausaha kelompok mahasiswa wirausaha di Universitas Pendidikan Ganesha.

Hipotesis penelitian Ketiga "Self Efficacy dapat memoderasi hubungan Pengetahuan Kewirausahaan terhadap Minat Berwirausaha". Berdasarkan Tabel 4.1, ketika Self Efficacy menjadi variabel moderasi memiliki koefisien korelasi sebesar $-0,055$ dengan nilai signifikansi $0,034<0,05$ dan nilai t hitung sebesar $-2,201$ lebih kecil dari t tabel 1,688 . Sehingga $\mathrm{H}_{1}$ ditolak yang berarti Self Efficacy berpengaruh negatif signifikan yang artinya Self Efficacy memperlemah hubungan Pengetahuan Kewirausahaan terhadap Minat Berwirausaha kelompok mahasiswa wirausaha di Universitas Pendidikan Ganesha.

\section{Pembahasan}

\section{Pengaruh Pengetahuan Kewirausahaan terhadap Minat Berwirausaha}

Berdasarkan pengamatan penulis bahwa, mahasiswa Universitas Pendidikan Ganesha rata-rata memiliki ketertarikan terhadap kegiatan wirausaha. Hal ini dibuktikan pada saat lembaga atau pun fakultas yang mengadakan kegiatan seminar bertemakan kewirausahaan mahasiswa selalu menunjukkan antusias mereka dalam menerima informasi. Mahasiswa juga memiliki ketertarikan terhadap pengalaman dan tips merintis usaha dari tokoh yang menjadi narasumber dalam seminar kewirausahaan. Selain itu, pada Program Mahasiswa Wirausaha ada 39 tim yang berhasil lulus dalam seleksi dari 80 tim yang mendaftarkan proposal wirausaha. Tujuan dari mendaftarkan proposal wirausaha tersebut agar mahasiswa dapat memiliki pengalaman dalam menjalankan sebuah usaha, bisa menjalankan ide usaha yang dibuat dengan dana yang diberikan oleh lembaga dan dapat merasakan pengalaman mendapatkan keuntungan dari hasil berwirausaha.

Dalam penelitian ini menujukkan bahwa pengetahuan kewirausahaan berpengaruh terhadap minat berwirausaha kelompok mahasiswa wirausaha pada Undiksha, yang didukung oleh penelitian yang dilakukan oleh Noviantoro dan Rahmawati (2017). Pengetahuan mengenai kewirausahaan disalurkan pada mahasiswa melalui kegiatan belajar mengajar di dalam kelas saat perkuliahan dan Undiksha rutin melaksanakan kegiatan seminar yang bertemakan kewirausahaan. Seminar yang diadakan juga mendatangkan tokoh yang menjadi pioner dalam dunia wirausaha, untuk meningkatkan daya tarik mahasiswa agar dapat mengikuti seminar kewirausahaan yang diadakan. Mahasiswa akan sangat antusias dalam mengikuti seminar apabila tema dan pembicara yang didatangkan menarik. Hasil ini sejalan dengan teori yang 
dinyatakan oleh Alma (2008) pendidikan formal dan pengalaman bisnis kecil dapat menjadi potensi bagi seseorang untuk menjadi wirausahawan yang berhasil.

\section{Pengaruh Self Efficacy terhadap Minat Berwirausaha}

Kegiatan praktek berwirausaha dapat memberikan pengalaman bagi mahasiswa yang diberikan kesempatan untuk menjalankan ide usahanya. Pengalaman tersebut menjadi sumber kepercayaan diri bagi mahasiswa untuk mengetahui sistem kerja dalam dunia wirausaha seperti, bekerja sama dengan teman satu tim, mengelola waktu kerja mulai dari produksi sampai menyalurkan produk, dan mengelola keuangan agar mendapatkan keuntungan. Berbekal pengalaman selama menjalankan ide usaha dapat menumbuhkan kepercayaan diri bagi mahasiswa sehingga dapat menuculkan minat mereka terhadap kegiatan wirausaha.

Dari hasil penelitian yang dilakukan menunjukkan adanya pengaruh self efficacy terhadap minat berwirausaha, hasil ini didukung oleh Mustofa (2014). Kegiatan kewirausahaan yang diprogramkan di Undiksha memberikan kesempatan bagi mahasiswa untuk mendapatkan pengalaman dalam mengelola sebuah usaha. Pengalaman tersebut dapat memunculkan kepercayaan diri mahasiswa untuk bergelut dan memiliki keyakinan dalam dunia wirausaha. Mahasiswa yang memiliki rasa percaya diri yang tinggi akan mampu mengambil keputusan dan mampu menghadapi tantangan dengan membuat strategi yang baik. Hasil penelitian ini sejalan dengan teori yang dinyatakan oleh Daryanto (2012:8) bahwa seorang wirausaha yang memiliki kepercayaan diri akan lebih optimis dan memiliki keyakinan atas kemampuannya untuk mewujudkan keberhasilan usaha.

\section{Pengaruh Variabel Moderasi Self Efficacy pada Hubungan Pengetahuan Kewirausahaan terhadap Minat Berwirausaha}

Berdasarkan pengamatan di lapangan, mahasiswa memiliki ketertarikan terhadap pengetahuan kewirausahaan namun belum berani untuk mempraktekkan informasi yang diterima dalam menjalankan sebuah usaha. Tidak semua mahasiswa yang memiliki pengalaman menjalanakn usaha menggunakan modal yang diberikan oleh lembaga, akan melanjutkan usahanya setelah menyelesaikan perkuliahaannya di Undiksha. Hal ini dikarenakan mahasiswa tersebut lebih memilih untuk mencari pekerjaan pada instansi tanpa perlu memikirkan resiko pada dunia wirausaha dan ada pengaruh dari keluarga lebih bahagia apabila anak-anak mereka menjadi pegawai negeri. Selain itu, mereka belum sepenuhnya memahami pengetahuan berwirausaha seperti aspek-aspek wirausaha dan kurang kesiapan dalam mengatasi resiko berwirausaha. Sebagian dari mereka memilih bekerja pada instansi untuk mengumpulkan modal terlebih dahulu sebelum membuka sebuah usaha. Kepemilikan modal awal menjadi hal yang dipertimbangkan bagi mereka untuk memilih mulai berwirausaha.

Hasil moderasi dalam penelitian ini menunjukkan bahwa self efficacy sebagai variabel moderasi justru memperlemah hubungan pengetahuan kewirausahaan terhadap minat berwirausaha. Kelompok mahasiswa wirausaha kurang memiliki kepercayaan diri dan keyakinan atas kemampuannya dalam mengelola usaha, sehingga tidak mampu mengelola sebuah usaha dengan baik. Ketakukan mahasiswa dalam mengelola sebuah usaha adalah takut meminjam modal usaha, tidak mampu mengelola tim kerja dan adanya ketakutan akan kemungkinan terjadinya resiko dalam prores menjalankan usaha. Jika seseorang memiliki pengetahuan mengenai kewirausahaan mereka belum tentu berani untuk mengambil langkah menjalankan usaha, hal ini karena mereka tidak memiliki rasa percaya diri yang kuat. Ada hal-hal yang menjadi pertimbangan mereka sebelum menentukan pilihan untuk berwirausaha, yang menyebabkan kurangnya kepercayaan diri dapat menurunkan minat berwirausaha. Hasil penelitian ini tidak sejalan dengan Suryana (2016) menyatakan bahwa seseorang yang minat berwirausaha dan memiliki pengetahuan kewirausahaan 
akan dipengaruhi oleh kepercayaan dirinya sebagai landasan untuk menciptakan sebuah usaha.

\section{SIMPULAN DAN SARAN \\ Simpulan}

Berdasarkan hasil penelitian dan pembahasan yang telah dijelaskan pada bab sebelumnya, maka dapat disimpulkan hal sebagai berikut: (1) Pengetahuan kewirausahaan berpengaruh positif signifikan terhadap minat berwirausaha dengan nilai koefisien korelasi sebesar 2,703 dengan nilai signifikansi $0,005<0,05$, hal ini berarti semakin banyak pengetahuan kewirausahaan yang diberikan pada mahasiswa maka akan semakin meningkatkan minat berwirausaha mahasiswa yang telah tergabung dalam kelompok mahasiswa wirausaha. (2) Self efficacy berpengaruh positif signifikan terhadap minat berwirausaha dengan nilai koefisien korelasi sebesar 1,740 dengan nilai signifikansi 0,011< 0,05 , hal ini berarti semakin tinggi tingkat kepercayaan diri mahasiswa dalam berwirausaha (self efficacy) maka semakin tinggi pula minat berwirausaha mahasiswa yang telah tergabung dalam kelompok mahasiswa wirausaha. (3) Self efficacy berpengaruh negatif signifikan dalam hubungan pengetahuan kewirausahaan terhadap minat berwirausaha dengan nilai koefisien korelasi sebesar $-0,055$ dengan nilai signifikansi $0,034<0,05$, hal ini berarti self efficacy justru memperlemah hubungan pengetahuan kewirausahaan terhadap minat berwirausaha.

\section{Saran}

Berdasarkan hasil penelitian, pembahasan dan simpulan yang dikemukakan, maka dapat diajukan beberapa saran sebagai berikut: (1) Bagi mahasiswa yang pernah tergabung dalam kegiatan kewirausahaan dan yang telah mendapatkan pengetahuan kewirausahaan, disarankan dapat lebih percaya diri atas pengalaman yang dimiliki serta diharapkan dapat lebih berani untuk mewujudkan inovasi dalam berwirausaha. Sehingga mampu meningkatkan persentase lulusan yang mandiri dalam dunia kerja. (2) Bagi Universitas Pendidikan Ganesha, hendaknya tetap memberikan fasilitas untuk menyalurkan pengetahuan kewirausahaan baik itu dengan seminar atau pun kegiatan belajar mengajar di kelas yang di kemas menjadi kegiatan menarik. Kegiatan praktik berwirausaha penting dilakukan sebagai bentuk pembelajaran bagi mahasiswa dalam menghadapi dunia wirausaha. (3) Bagi peneliti lain yang berminat untuk menguji tentang minat berwirausaha, disarankan dapat mengembangkan penelitian ini pada organisasi lain dengan jumlah sampel yang lebih luas. Hal ini berguna untuk menguji keberlakuan sebuah penelitian agar hasilnya lebih maksimal. Selain itu, peneliti berikutnya dapat menggunakan variabel bebas lainnya yang dapat mengukur minat berwirausaha, seperti ketersediaan modal usaha.

\section{Daftar Pustaka}

Alma, Buchari. 2008. Kewirausahaan Untuk Mahasiswa dan Umum. Bandung: Alfabeta.

Andika, Manda dan Iskandarsyah Madjid. 2012. "Analisis Pengaruh Sikap, Norma Subyektif dan Efikasi Diri Terhadap Intensi Berwirausaha Pada Mahasiswa Fakultas Ekonomi Universitas Syiah Kuala (Studi Pada Mahasiswa Fakultas Ekonomi Universitas Syiah Kaula)". Eco-Entrepreneurship Seminar \& Call for Paper "Improving Performance by Improving Environment" Fakultas Ekonomi, Universitas Negeri Semarang (hlm.19 -197).

Anggraeni, Bety dan Harnanik. 2015. "Pengaruh Pengetahuan Kewirausahaan dan Lingkungan Keluarga Terhadap Minat Berwirausaha Siswa Kelas XI SMK Islam Nusantara Comal Kabupaten Pemalang". Jurnal Pendidikan Ekonomi Dinamika Pendidikan, Volume X, Nomor 1 (hlm.42-52).

Anggraeni, Dewa Ayu Lia dan I Nyoman Nurcaya. 2016. "Peran Efikasi Diri dalam Memediasi Pengaruh Pendidikan Kewirausahaan Terhadap Niat Berwirausaha". E-Jurnal Manajemen Unud, Volume 5, Nomor 4 (hlm.2424-2453). 
Aprilianty, Eka. 2012. "Pengaruh Kepribadian Wirausaha, Pengetahuan Kewirausahaan, dan Lingkungan Terhadap Minat Berwirausaha Siswa SMK". Jurnal Pendidikan Vokasi, Volume 2, Nomor 3 (hlm.311-324).

Artiandewi, Aninda. 2016. Pengaruh Efikasi Diri Berwirausaha dan Pendidikan Kewirausahaan Terhadap Intensi Berwirausaha Mahasiswa Pendidikan Administrasi Perkantoran Universitas Negeri Yogyakarta. Skripsi Program Studi Pendidikan Administrasi Perkantoran, Fakultas Ekonomi. Yogyakarta: Lumbung Pustaka Unversitas Negeri Yogyakarta.

Bagheri, Afsaneh, et al. 2013. "Entrepreneurial Leadership Self efficacy: A Focus on Malaysian Student Entrepreneurial Leaders". Journal of Education, Volume 66, Nomor 1 (hlm.690 -708).

Daryanto. 2012. Pendidikan Kewirausahaan. Yogyakarta: Penerbit Grava Media.

Ekpe, Isidore \& Norsiah Mat. 2012. "The Moderating Effect of Social Environment on The Relationship Between Entrepreneurial Orientation and Entrepreneurial Intentions of Female Studen at Nigerian Universities". International Journal of Management Sciences and Business Research, Volume 1, Nomor 4 (hlm.1-16).

Ghozali, Imam. 2011. Aplikasi Analisis Multivariate Dengan Program IBM SPSS 19. Edisi ke 5. Semarang: Badan Penerbit Universitas Diponegoro.

Mustofa, Arif Muchammad. 2014. Pengaruh Pengetahuan Kewirausahaan, Self Efficacy, dan Karakter Wirausaha Terhadap Minat Berwirausaha Pada Siswa Kelas XI SMK Negeri 1 Depok Kabupaten Sleman. Skripsi Program Studi Pendidikan Ekonomi, Fakultas Ekonomi. Yogyakarta : Lumbung Pustaka Unversitas Negeri Yogyakarta.

Noviantoro dan Rahmawati. 2017. "Pengaruh Pengetahuan Kewirausahaan, Motivasi Berwirausaha dan Lingkungan Keluarga Terhadap Minat Berwirausaha Pada Mahasiswa Akuntansi FE UNY". Jurnal Profita Kajian IImu Akuntansi, Volume 6, Nomor 1 (hlm. 1-10)

Owoseni, Omosolape Olakitan. 2014. "The Influence of Some Personality Factors on Entrepreneurial Intentions". International Journal of Business and Social Science, Volume 5, Nomor 1 (hlm.278-284).

Puspitaningsih, Flora. 2014. "Pengaruh Efikasi Diri Dan Pengetahuan Kewirausahaan Terhadap Minat Berwirausaha Melalui Motivasi”. Jurnal Ekonomi Pendidikan dan Kewirausahaan, Volume 2, Nomor 2 (hlm. 224-236).

Roxas, et all. 2008. "Entrepreneurial Knowledge and its Effects on Entrepreneurial Intentions: Development of a Conceptual Framework". Asia - Pacific Social Science Revie, Volume 8, Nomor 2 (hlm. 61-77)

Sugiyono. 2010. Statistika Untuk Penelitian. Bandung: CV Alafebta. 2016. Statistika Untuk Penelitian. Bandung: Alfabeta.

Suparyanto. 2016. Kewirausahaan Konsep dan Realita Usaha Kecil. Bandung: Alfabeta

Suryana. 2016. Kewirausahaan Kita dan Proses Menuju Sukses edisi 4. Jakarta: Salemba Empat. 
Ulfatum, Titik, dkk. 2015. "Pengaruh Program Mahasiswa Wirausaha Terhadap Minat Berwirausaha Mahasiswa Fakultas Ekonomi UNY Tahun Angkatan 2011 dan 2012". Pelita, Volume 10, Nomor. 1 (hlm. 53-64).

Uswaturrasul, Yahya dan Kristina Sisilia. 2015. "Analisis Minat Dan Motivasi Berwirausaha Mahasiswa (Studi Pada Program Studi Administrasi Bisnis Telkom University Angkatan 2011)". Jurnal e-Proceeding of Management, Volume 2, Nomor. 3 (hlm. 3586-3596).

Wiyanto, Hendra. 2014. "Pengaruh Efikasi Diri dan Lingkungan Terhadap Minat Berwirausaha Mahasiswa (Studi Pada Mahasiswa Program Studi Manajemen Fakultas Ekonomi Universitas Tarumanagara)". Jurnal Manajemen, Volume 18, Nomor 1 (hlm.114-129). 